\title{
REFORMA DE LOS MONASTERIOS DE LOBÁS, DOZÓN Y ANSEMIL (1498-99)
}

\author{
Por \\ ERNESTO ZARAGOZA PASCUAL
}

\section{RESUMEN}

Se trata de la publicación de 20 documentos inéditos sobre la reforma de los monasterios de benedictinas gallegos de San Pedro de Lobás, San Pedro de Dozón y San Pedro de Ansemil, hecha por el prior de San Benito de Valladolid, fray Rodrigo de Valencia, que incluye los procesos sobre la vida monástica de sus últimas abadesas reunidas luego en el nuevo monasterio de San Payo de Antealtares de Santiago de Composela.

\section{PALABRAS CLAVE}

Monasterios, benedictinas, reforma.

\section{ABSTRACT}

Twenty unpublished documents are published on the reform of the monasteries of Benedictine Galicians of San Pedro de Lobás, San Pedro de Dozón and San Pedro de Ansemil, done by the prior of San Benito of Valladolid, monk Rodrigo de Valencia, that it includes the processes on the monastic life of his last abbesses then in the new monastery San Payo's de Antealtares of Santiago de Compostela.

\section{KEYWORDS}

Monasteries, Benedictine, Reforms. 
Presentamos aquí una documentación inédita sobre la reforma llevada a cabo por el prior de San Benito de Valladolid, Fray Rodrigo de Valencia, entre 1498 y 1499, como reformador general de la Orden de San Benito en Galicia, por encargo del Papa Alejandro VI y comisión de los Reyes Católicos, de los monasterios de monjas benedictinas de San Pedro de Lobás o Lobanes ${ }^{1}$, San Pedro de Dozón ${ }^{2}$ y San Pedro de Ansemil ${ }^{3}$. El primero estaba situado en O Carballiño, dentro de la provincia y diócesis de Ourense; el segundo en Vilanova de Dozón y el tercero en Silleda, ambos dentro de la actual provincia de Pontevedra y, entonces, diócesis de Lugo.

Se trata de los procesos hechos contra Doña. Inés de Sanabria, abadesa de Lobaes ${ }^{4}$ y contra Dña. Isabel de Ulloa, abadesa de los monasterios de Dozón y de Ansemil ${ }^{5}$, juntamente con las actas de visita y tomas de posesión de estos tres monasterios, que finalmente fueron unidos al de San Payo de Antealtares ${ }^{6}$.

Según esta documentación, el 16 de octubre de 1498 el prior reformador citó a la abadesa de Lobás para que compareciese personalmente ante él en Santiago para responder de las acusaciones que le hacía el fiscal de la orden benedictina en Galicia, Fernando de Estrada ${ }^{7}$. En su ausencia -pués había huido por miedo al reformador- la citación le fue notificada tres días después por el notario Juan Rodríguez, clérigo, que la fijó en las puertas de la iglesia monasterial. Pero como no compareció la abadesa, ésta fue declarada rebelde los días 20,22 y 24 del mismo mes, ante el notario Ochoa Ibáñez de Estella.

El 17 de noviembre del mismo año el visitador delegado, fray Juan de Manzaneda, abad de Bergondo, visitó el monasterio de Lobás y tras dejar

${ }^{1}$ Cf. DURO PEÑA, E., «El monasterio de San Pedro de Lobanes», en Compostellanum, núm. 13 (1968), 287-335, que desconoce esta documentación del AHN.

${ }^{2}$ Cf. ID., «El monasterio de San Pedro de Vilanova de Dozón», en Archivos Leoneses, núm. 43 (1968), 7-62.

${ }^{3}$ COLOMBÁS, G.M., Las señoras de San Payo, Santiago de Compostela, 1980, 74-75.

${ }^{4}$ Fue abadesa desde 1486 ó 1488 a 1499, siendo la última que tuvo el monasterio, Cf. DURO, E, o.c. en la nota 1, p. 298; y COLOMBÁS, G.M., o.c., p. 41.

${ }^{5}$ Acaso era de la familia de los Condes de Monterrei. Aparece ya como abadesa en 1483, Cf. DURO, E., o.c. en la nota 2, p. 23.

${ }^{6}$ Cf. COLOMBÁS, G.M., o.c., p. 73-74.

${ }^{7}$ Cf. Doc. núm. 1.

«CUADERNOS DE ESTUDIOS GALLEGOS», Tomo XLIX, Fascículo 115, Santiago 2002. 
ciertas disposiciones para organizar la vida de comunidad ${ }^{8}$, el 19 emplazó a la abadesa para que acudiese a Santiago ante el reformador 9 . Pero como no compareció, el fiscal pidió al reformador que la declarara en rebeldía y la privase de su abadía, por tenerla desde hacía diez o doce años sin título legítimo y por haber vivido disolutamente, sin guardar la regla, ni vivir en comunidad, amancebada públicamente con clérigos y seglares, de los que había tenido hijos, y haber disipado los bienes del monasterio ${ }^{10}$. Fue citada de nuevo el 3 de diciembre siguiente ${ }^{11}$, cuya notificación fue puesta en las puertas de la iglesia del monasterio de Lobás el 14 del mismo mes. Mas, como no compareció, fue declarada rebelde los días 18,20 y 22 siguientes ${ }^{12}$.

En efecto, el 20 de diciembre, Diego Alonso, procurador de la abadesa, presentó un alegato en que recusaba al reformador como juez, por no tener -decía- jurisdicción sobre las monjas, por no poder pedir a dicha abadesa que abandonase su monasterio y compareciese personalmente, además que ella estaba enferma y tenía miedo de que la encerrase en San Payo, como había hecho con otras monjas. Y que si no aceptaba su alegato, apelaba al Papa ${ }^{13}$. Pero el reformador el día 22 renovó su mandato para que la dicha abadesa compareciera personalmente ante él, y así se lo notificó dos días después a dicho procurador. El 29 del mismo mes, el reformador se pronunció como juez apostólico competente, denegó la apelación de Diego Alonso, pero le dio tres días para presentar el testimonio de la enfermedad de dicha abadesa ${ }^{14}$. Esta no compareció, y así se dio por concluido el pleito ${ }^{15}$.

Por su parte, Fernando de Estrada nombró físcal delegado a Pedro de Villarroel, vecino de Sahagún, en San Salvador de Chantada, el 7 de junio de 1499. El reformador, ante la ausencia de la abadesa del monasterio de Lobás, mandó al notario Gonzalo de Nájera notificarle por última vez la

\footnotetext{
${ }^{8}$ Cf. Doc. núm. 2.

${ }^{9}$ Cf. Doc. núm. 3.

${ }^{10}$ Cf. Doc. núm. 4.

${ }^{11}$ Fue citada por el reformador, con la misma fórmula enviada a la abadesa de Dozón, Cf. Doc. núm. 17.

${ }^{12}$ AHN, Clero, Leg. 7706, Libro de registro notarial.

${ }^{13}$ Cf. Doc. núm. 5.

${ }^{14}$ Cf. Doc. núm. 6 y 7.

${ }^{15}$ Cf. Doc. núm. 8.
} 
citación, clavándola en las puertas de la iglesia de dicho monasterio. En ella declaraba que si no acudía la juzgaría en rebeldía. Fueron testigos de dicha citación, los benedictinos observantes fray Pedro de Zamora y fray Rodrigo de Peñafiel, el licenciado Alonso de Pomareda, corregidor de Sarria y Diego Velón, merino de Samos, Fernando Mourín, Luis de Ribadeo, Juan de Frejo, Lope Osorio y Alfonso Vázquez, criados de Fernando de Camba y otros ${ }^{16}$.

El reformador visitó personalmente el monasterio de Lobás el 8 de junio, donde una vez más emplazó para dentro de tres días a la abadesa, que había huido del monasterio llevando consigo muchas cosas del mismo. Visitó la iglesia y sus altares, ornamentos y libros - cuyo catálogo detalla- y el monasterio, casi desprovisto de todo ${ }^{17}$.

Todavía el día 10 del mismo mes emplazó a las partes para que compareciesen ante él dentro de nueve días ${ }^{18}$. En el mismo día, el fiscal substituto presentó copia de las bulas de Inocencio VIII, Quanta in Dei Ecclesia $(11-X I I-1487)^{19}$ y de Alejandro VI, Alias felicis recordationis (26-III$1494)^{20}$, y mandó tomar declaración a cinco testigos moradores del coto de Lobás, por el interrogatorio de nueve preguntas, sobre la vita et moribus de la dicha abadesa y sus monjas. Los cinco se ratificaron en lo que anteriormente habían dicho ante el notario Fernando Martínez de Sta. Gadea ${ }^{21}$, cuyo testimonio no hemos podido hallar. A continuación, dicho fiscal substituto, solicitó copia de la pesquisa hecha en el monasterio de Sobrado de Trives, donde había profesado Dña. Inés de Sanabria, para incorporarla al proceso -pero por descuido no se incorporó en él-.

${ }^{16}$ AHN, Clero, Leg. 7706 (Original).

${ }^{17}$ Cf. Doc. núm. 9.

${ }^{18}$ Cf. Doc. núm. 10.

${ }^{19}$ Además de la copia existente en el AHN, Clero, Leg. 7706, hay otra en el Archivo Secreto Vaticano, Registro 727, ff. 249v-256v, publicada por J. GARCÍA ORO, en La reforma de los religiosos españoles en tiempos de los Reyes Católicos, Valladolid, 1969, p. 49-53.

${ }^{20}$ De esta bula, además de la copia del AHN, Clero, Leg. 7706, hay otras copias en Archivo General de Simancas, Patronato Real, Lib. 28, ff. 312r-319r; Libros de copias, Lib. 34, ff. 15r-20r, publicada por E. ZARAGOZA en Los generales de la Congregación de San Benito de Valladolid, I, Silos, 1973, p. 261-263.

${ }^{21}$ Cf. Doc. núm. 11.

«CUADERNOS DE ESTUDIOS GALLEGOS», Tomo XLIX, Fascículo 115, Santiago 2002. 
Por su parte el reiormador dio a la dicha abadesa otros quince días de plazo para que compareciera ante él en San Martín de Santiago, clavando la citación en las puertas de la iglesia del monasterio.

En este mismo día 10 de junio depusieron dos testigos más, que tras ratificarse en lo que con anterioridad tenía declarado, preguntados por el reformador, dijeron que efectivamente la abadesa se había ausentado voluntariamente, y que había oído decir que se había llevado cuanto había de valor en el monasterio. Y uno de ellos añadió, que la dicha abadesa había sido puesta por Don Fernando de Camba, cuando la anterior, llamada Sancha Rodríguez, habiendo perdido el juicio, abandonó el monasterio para refugiarse en casa de su madre y parientes ${ }^{22}$.

Así que el 24 fue declarada en rebeldía, el 25 se publicó, el 27 se dio por acabado el proceso y el 28 la citó de nuevo en Santiago para oír la sentencia definitiva. Esta citación fue clavada en las puertas del monasterio el 4 de julio ante el notario Alfonso de Villarablo, clérigo, y los testigos Juan y Alonso de Sotodavilla, moradores en el coto de Lobás y otros ${ }^{23}$.

La sentencia definitiva la dio el reformador el 8 de julio, privándola de la abadía y mandándole recluirse en San Payo dentro de 20 días, de donde no podría salir sin licencia del reformador, so pena de ser habida por apóstata y excomulgada, la condenó al pago de costas de dicho proceso ${ }^{24}$, y al día siguiente mandó ejecutar la sentencia y tomar posesión del monasterio en nombre de la Orden y para la Observancia ${ }^{25}$.

El 19 del mismo mes, Diego Alonso apeló de la sentencia ${ }^{26}$, pero el 23, el reformador denególe la apelación, por no haber comparecido personalmente dicha abadesa, por no haberle hecho él a ella agravio alguno y por haber sido presentada fuera de tiempo, siendo testigos principales fray Gonzalo de San Vivencio y fray Jácome de Santiago, antiguos abades de los monasterios de Sta. María de Mezonzo y San Antonino de Toques. Y con esto se acabó el pleito.

${ }^{22}$ Cf. Doc. núm. 12. Sancha Rodríguez era ya abadesa en 1483, Cf. E. DURO, o.c. en nota 1, p. 297.

${ }^{23}$ Cf. Doc. núm. 13.

${ }^{24}$ Cf. Doc. núm. 14.

${ }^{25} \mathrm{Cf}$. Doc. núm. 15. De este documento y del de la nota anterior hay un ejemplar en el Archivo Hist. Prov. de Orense, Libro 1247, f. 541, resumidos por E. DURO, en o.c. en la nota 1, p. $317-320$.

${ }^{26}$ Cf. Doc. núm. 16.

«CUADERNOS DE ESTUDIOS GALLEGOS», Tomo XLIX, Fascículo 115, Santiago 2002. 
El 4 de diciembre de 1498 el reformador había citado en Santiago a Dña. Isabel de Ulloa, abadesa de los monasterios de Dozón y Ansemil para responder de las acusaciones que le hacía el fiscal, de no guardar la regla ni las constituciones, y de cometer «muchos delictos e excessos dignos de gran pugnaçión e castigo en grand offensa de Dios nuestro señor e en gran ynfamia e en muy mal exiemplo de todas las otras religiosas de la dicha horden», y además de dilapidar y enajenar los bienes del monasterio. Esta citación le fue notificada el 20 del mismo mes en el monasterio de Ansemil, por el notario Francisco de Rojas, siendo testigos el capellán Juan Rodríguez, Guillermo de Ansemil, Pedro de Candanedo $\mathrm{y}$ otros.

Mas como la abadesa no se presentó ni envió procurador en su lugar, fue declarada en rebeldía los días 23, 24 y 29 de diciembre. Y el 3 de enero de 1499 el procurador dio el proceso por concluido ${ }^{27}$. La muerte de la abadesa, que sucedió poco después, facilitó al reformador la toma de posesión del monasterio de Dozón, que se hizo el 11 de junio, con el ceremonial acostumbrado y en presencia de la priora Aldara Sánchez o López, que le dio la obediencia, y tras ordenar a los vasallos, feligreses, foreros y renteros que acudieran con sus rentas sólo a él o a quien su poder tuviere, visitó los altares, ornamentos, objetos y libros litúrgicos, dejó como moradora hasta nueva orden a la dicha priora y como capellán al clérigo Bernal Fernández para que administrara los sacramentos a los feligreses ${ }^{28}$.

El 13 del mismo mes, el reformador tomó posesión del monasterio de Ansemil, levantó el secuestro de los bienes que tenía Martín Alvares por encargo del corregidor de Sarria, Alonso de Pomareda, y finalmente visitó la iglesia del monasterio, haciendo relación de sus altares, ornamentos, libros y cálices ${ }^{29}$.

Esta es la información fundamental que nos proporcionan los 20 documentos inéditos que aquí publicamos, conservados en el Archivo Histórico Nacional de Madrid (=AHN), Sec. de Clero secular y regular, entre la documentación perteneciente al archivo del monasterio de San Benito de Valladolid, adonde la llevarían los reformadores o sus acompañantes.

\footnotetext{
${ }^{27}$ Cf. Doc. núm. 17 y 18.

${ }^{28}$ Cf. Doc. núm. 19.

${ }^{29}$ Cf. Doc. núm. 20.
} 
En su transcrición hemos respetado siempre el texto en todas y cada una de sus partes, así como la variable ortografía. Únicamente hemos puesto la puntuación y acentos ortográficos para hacer más fácil su lectura.

Esperamos que esta documentación arroje un poco más de luz sobre la reforma benedictina en Galicia en el siglo XV.

\section{DOCUMENTO 1}

1498, octubre, 16. Santiago.

Citación del reformador a la abadesa de Lobanes para que comparezca ante él a responder de los cargos que le hace el fiscal.

AHN, Clero, Leg. 7706 (Original).

Nos fray Rodrigo de Valençia, prior del monesterio de Sant Benito de Valladolid, general reformador de la orden de Sant Benito en los reynos de Castilla e Galizia con la provinçia del Bierzo, dado e deputado por el nuestro muy sancto padre Alexandro Sesto, moderno, a suplicaçión de los reyes nuestros señores, e con poderes, abtoridad e mandado fazemos saber a vos doña Ynés de Sanabria, abadesa del monesterio de Sant Pedro de Lobanes, que es de la orden de nuestro padre Sant Benito, de la diócesi de Orense, que ante nos paresçió Fernando de Estarda, vecino de la cibdad de Sanctiago, promotor fiscal de la dicha orden, e presentó e denunció ante nos ciertas querellas e denunciaçiones contra vos la dicha abadesa, e nos pidió nuestra carta citatoria contra vos sobre la dicha razón, e nos veyendo que nos pedía justiçia, mandamos se la dar en la forma siguiente. Porque vos mandamos en virtud de obediençia e so pena de excomunión mayor latae sententiae trina canonica monitione premisa, auctoritate appostolica de que en esta parte usamos, parezcáys ante de nos personalmente a responder las dichas querellas, denunçiaçiones e a alegar de vuestra justiçia, desde el día que esta nuestra carta vos fuere leyda e notificada en vuestra persona, podiendo ser avida, y sy non ante las puertas de vuestro monesterio o morada faziéndolo saber a vuestros criados o parientes o vezinos más cercanos, de manera que venga a vuestra notiçia e dello no podays pretender ignorançia, fasta seys días prostrimeros syguientes, los 
quales vos damos e asynamos por tres plazos e por tres canónicas moniçiones, dándovos los dos días primeros por primera moniçión, e los dos días segundos por segunda moniçión e los otros tres días por terçera moniçión e término perentorio, e os apercibimos que nos faremos, que si dentro del dicho término de seys días paresçedes oyrvos somos e en todo vos guardaremos cumplidamente vuestra justiçia. En otra manera, sin vos más llamar ni carta ni para ello atender no paresçiendo, el dicho término pasado, en vuestra absençia e rebeldía proçederemos en todo lo quel dicho fiscal cntra vos la dicha abadesa del dicho monesterio de Santa María (sic) de Lobanes dezir e alegar quisiere, lo qual vos mandamos que asy fagáys e cumpláys so la dicha pena de excomunión, por virtud de los poderes apostólicos e reales que para la reformaçión tenemos, los quales poderes, como son muy públicos e notorios en todo este dicho reyno, non mandamos aquí enxerir por su grande prolixidad, pero mandamos dar copia e treslado dellos a quien los quisyere del presente escrivano, pagándole su justo e devido salario. Dada en el nuestro monesterio de Sant Martín desta cibdad de Sanctiago, a diez y seys días de octubre, año del Señor de mill e quatro çientos e noventa e ocho años.

(Firmado:) Frater R.V ${ }^{\mathrm{a}}$, Sancti Benedicti prior et apostolicus reformator.

Por mandado de su reberencia. Juan Morales, notario.

\section{DOCUMENTO 2}

1498, noviembre, 17

\section{Acta de visita del monasterio de San Pedro de Lobanes.}

AHN, Clero, Leg. 7706 (Original).

En el monesterio de Sant Pedro de Lobanes, a diez e siete días del mes de noviembre, año de mill e quatroçientos e noventa e ocho años, en las casas que se mandaron hazer a la señora doña Ynés de Syabria (sic), abbadesa del dicho monesterio de Sant Pedro de Lobanes e a sus religiosas por el reverendo padre fray Iohan de Mançaneda, abbad de Bergundo, vysitador e reformador por el reverendo señor e padre don fray Rodrigo de Valençia, prior de Sant Benito de la villa de Valladolid, 
general reformador en este reyno de Galizia, allende de lo también ser en los reynos de Castilla en los monesterios de la horden de Sant Benito, son los siguientes:

Primeramente, que quando rezaren las horas, la madre abbadesa e monjas asy de día como de noche, que las no rezen syn tener lumbre ni la lámpara ni candela de çera.

Yten, se manda a la señora abbadesa e monjas, que alomenos cada mes una vez dispongan a confesar e comulgar como buenas religiosas.

Yten, se manda a la dicha señora abbadesa que non tenga a Alonso Fernández, capellán que agora tiene en casa, desde dya de Nabidad primera que viene del presente año en adelante, e desde allí que cate otro capellán, que pase de quarenta o cinquenta años, onesto, para que sea capellán en el dicho monesterio, ni enseñe moço ni moça a leer, salvo sy fuera moça para monja.

Yten, se manda a la señora abbadesa, que ningún hombre ni muger entre dentro del dicho monesterio, cámaras e offiçinas dél, salvo que quando el señor Fernando de Camba, viniere a ver su fija, que entre dentro solo, con tal condiçión que non coma ni beba ni duerma dentro, e esomesmo los ofiçiales que obieren de labrar o trabajar en las obras, que puedan entrar dentro e comer e beber, mas no dormir.

Yten, se manda a la madre abbadesa e monjas non salgan de la clausura de su monesterio, salvo que puedan salir las monjas a la huerta junto con las paredes del monesterio sy la señora abbadesa les mandare o diere liçencia o con la madre abbadesa a fazer la huerta, ni fablen con algund onbre ni muger, salvo en presençia de la abbadesa o con su liçençia.

Yten, se manda a la madre abbadesa que dentro de un mes primero siguiente faga poner dos fechaduras con sus llaves e herrojos, la una a la puerta que está a la entrada del monesterio, donde llaman los que vienen, e otra a la puerta de la huerta; e dentro del dicho término se manda a la madre abbadesa mande çerrar de pared la entrada que está abierta para obaçellar nuevo (sic) fasta lo más alto de la otra pared e más ençima media braça e que faga çerrar la nesçesaria fasta arriba, e poner una ventana reçia en la obertura que está en la sala enfrente de la filarera.

Yten, se manda a la madre abbadesa, que dentro de tres messes próximos que vienen mande levantar el muro que está en la puerta de la huerta, 
entre la casa del horno e la otra casa de la bodega, quanto una braça e otro tanto las otras paredes que están todo enderredor donde está la canal del agua.

Yten, se manda a la madre abbadesa e religiosas, que de noche ni de día fablen en la iglesia abaxo, ni en el choro de arriba, salvo lo que rezaren o sy la madre abbadesa corrigiere a alguna monja quando rezare.

Yten, se manda a la madre abbadesa, que dentro de dos meses primeros syguientes faga quitar la escalera que desçiende del choro a la iglesia, e çierre ençima por donde está puesta la escalera sobredicha.

Yten, se da logar a la madre abbadesa que sy alguna religiosa estoviere enferma en cama, que pueda resçebir físyco para que la cure o esomeso clérigo o frayre ançiano e honesto para que la oya de confessyón e penitençia.

Yten, se manda a la dicha madre abbadesa que faga çerrar los dos terçios de la ventana que está en la sala donde comen, dexando contra la parte de ençima un terçio por çerrar e aun menos, por donde entre alguna claridad en la dicha sala, e haga esomesmo çerrar la ventana que sale del forno a la mano ysquierda contra la huerta. Danse para esto término de dos meses primeros que vienen.

Yten, se permite e da logar a la dicha madre abbadesa e religiosas que puedan tener dentro consigo una muger o dos de serviçio e para ser porteras, contando que las tales mugeres o moças sean tales, que se non pueda aver alguna mala suspeçión.

Yten, se manda a la madre abbadesa, que dentro de los tres meses primeros syguientes, mande çerarr de piedra e barro la ventana de la capilla mayor, que está a la mano yzquierda e haga poner una cruz de hierro en el espejo de la mesma capilla, e otra barra de hierro fasya en la otra ventana que está a la mano derecha, bien fuertemente, todo esto con pico e plomo, porque por ellas non pueda entrar onbre ni muger.

Yten, se manda a la madre abbadesa non permita de aquí en adelante entrar puercos ni criarlos dentro de la clausura del dicho monesterio.

Yten, se manda a la madre abbadesa que dentro de ocho meses primeros que vienen, faga conprar paño honesto lo más negro que fallare e de poco preçio, para que se fagan cogullas asy para ella como para las otras religiosas, las quales sean sin capilla con sus mangas anchas.

Yten, se manda a la madre abbadesa que de aquí adelante ni ella ni sus religiosas non traygan ropa clara ni blanca ni de otra color, salvo parda o 
negra. E que puedan continuamente traher la que agora tienen fasta que se rasgue.

Yten, se manda a los vasallos del dicho monesterio que con los cuerpos e con las fasyendas ayuden e syrvan a la señora abbadesa para fazer todo lo que arriba se manda fazer o otras qualesquier cosas que sean nesçesarias al dicho monesterio, so pena de excomunión e más las penas tenporales que la señora abbadesa moderadamente les posyere.

Todo lo sobredicho fue e pasó dentro en el dicho monesterio de Sant Pedro de Lobanes, a diez e syete días del mes de noviembre, año de mill e quatroçientos e noventa e ocho años. Por mandado de dicho reverendo padre abbad de Bergundo, fray Juan de Mançaneda, visitador e reformador susodicho, a la dicha abbadesa de Lobanes doña Ynés de Senabria e a sus monjas en sus personas fue mandado lo guardasen e cunpliesen en virtud de santa obediençia e so pena de excomunión, e esomesmo a la señora abbadesa, allende de las sobredichas penas, de privaçión de su dignidad e abbadía, e lo pedía por testimonio a mí el dicho notario e rogava a los presentes fuesen testigos; e la dicha abbadesa dixo que como fija de obediençia obedesçía el dicho mandamiento e regla e reformaçión susodicha, e que protestava de cunplir lo mejor que ella pudiese, non perjudicando sy alguna cosa a que tenía Sant Benito. Esto fue e pasó en el dicho día, mes e año susodicho, en el dicho monesterio de Lobanes, estando presentes por testigos Fernando Rodríguez, veçino e regidor de la cibdad de Sanctiago e Alberte Fernandes e Alvaro de More e Estevan Rodríguez e otros.

Yo Álvaro Janero, notario público jurado por la abtoridad apostolical, a todo lo que dicho es e fue mandado por el dicho abad de Vergondo a la dicha abadesa de Lobanes, en uno con los dichos testigos presente fuy e segund que ante mí pasó e fue, mandó, bien y fielmente lo fize escrivir, e por ende por mandado del reverendo padre prior de Sant Benito fize aquí este mi signo e nonbre, que tal es, en testimonio de verdad; la qual dicha visitaçión yo notario dexé a la dicha abadesa de Lobanes signada de mi signo e firmada de dicho padre abad de Vergondo. Alvaro Janero, notario apostólico. 


\title{
DOCUMENTO 3
}

1498, noviembre, 19. Lobanes.

Citación del visitador para que la abadesa de Lobanes compareciera a declaran ante él.

AHN, Clero, Leg. 7706 (Original).

En el monesterio de Sant Pedro de Lobanes, día lunes, diez e nueve dyas del mes de nobiembre de noventa e ocho años, mandó el dicho abbad de Vergundo, visytador, a la señora doña Ynés de Senabria, abbadesa de Lobanes, que dentro de nueve dyas primeros syguientes paresçiese delante del reverendo padre prior de Sant Benito de Valladolid, al qual acudiese donde estava e estoviese por santa obediençia e sopena de excomunión en propria persona a responder de la demanda que le porná el fiscal de la horden. Testigos que la vieron emplazar: Fernando Ruiz, veçino de Sanctiago e Lope Osorio, escudero, criado de Fernando de Coba, e Alonso Fernández, capellán, e Alverte Fernández, veçino de Sanctiago.

\section{DOCUMENTO 4}

1498, diciembre, 1. Santiago

Petición del fiscal al reformador de que la abadesa de Lobanes sea condenada en rebeldía por no haber comparecido en el plazo señalado.

\author{
AHN, Clero, Leg. 7706 (Original).
}

Muy reverendo señor e devoto padre: Fernando de Estrada, promotor fiscal de la horden de nuestro padre Sant Benito beso las manos a vuestra merçed, ante la qual en la mejor forma e manera que puedo y con derecho devo, me querello de doña Ynés de Senabria, abbadesa que dise ser del monesterio de Sant Pedro de Lobanes, ques de la dicha horden de Sant Benito, e digo que puede aver dies o dose años poco más o menos que la dicha doña Ynés syn tener título ni ynstituçión canónica de la dicha abbadía, 
ni seyendo elegida en la forma que de derecho se requiere, ni por personas que toviessen poder ni jurediçión, se entrometió a entrar e entró en el dicho monesterio, e le ha tenido e tiene yntruso y ocupado des del dicho tienpo acá, en perjuyzio de la dicha horden, y lo que peor es, después que asy se dixo e nonbró abbadesa del dicho monesterio, ha bivido muy disolutamente, non guardando la regla ni horden de nuestro padre Sant Benito ni ha bibido en comunidad ni guardando ninguna de las otras cosas que de derecho e segund la dicha regla devía guardar, ni tanpoco ha guardado castidad, antes ha seydo muy yncontinente de su cuerpo, y a seydo públicamente amançebada assy con clérigos como con personas legas, aviendo fijos dellos en grand deserviçio de Dios e obprobio de la dicha religión e en muy mal exienplo de las otras religiosas; e demás desto, ha disipado e destruydo los bienes del dicho monesterio, enagenándolos en casos prohibidos e non reparando el dicho monesterio, ni trayendo el ábito como devía segund la regla de la dicha horden, bibiendo e traspasando en todo contra la dicha regla. Por ende, a vuestra merced pido que como juez apostólico e reformador breve e sumariamente me faga cerca de lo susodicho entero cunplimiento de justiçia, condenando a la dicha doña Ynés de Senabria a pena de pribaçión de la dicha abbadía en caso que aquélla se falle ser abbadesa, declarando por los dichos excesos e delictos e quebrantamientos de la dicha regla e constituçiones de aquélla dever ser privada de la dicha abbadía, e más le condepne en las otras penas que de derecho e segund en las dichas constituçiones fallare que aquella meresçe executándolas en su per̀sonas por que a ella sea castigo e enxienplo a las otras religiosas, e para ello su ofiçio ynploro e pido cunplimiento de justiçia e las costas.

\section{DOCUMENTO 5}

1498, diciembre, 20. Santiago.

Alegato del procurador de la abadesa de Lobanes, Diego Alonso.

AHN, Clero, Leg. 7706 (Original).

Reverendo señor don fray Rodrigo de Valençia, prior del monesterio de Sant Benito de Valladoid, yo Diego Alonso, en nonbre de doña Ynés

«CUADERNOS DE ESTUDIOS GALLEGOS», Tomo XLIX, Fascículo 115, Santiago 2002. 
de Sanabria, abadesa del monesterio de Lovanes, con protestaçión que hago de no dar avuestra reverençia más jurediçión de la que de derecho tyene, me presento ante vos e digo que es venido a mi noticia cómo a pedimiento de Fernando Destrada, vuestra reberençia mandó dar e dio una carta de enplazo de citaçión personal contra la dicha mi parte, en que le mandó que paresçiese personalmente en esta cibdad de Santiago so çiertas penas en la dicha carta contenidas, la qual dicha carta e citaçión a la dicha mi parte fecha, digo ser ninguna o de alguna que la dicha mi parte fecha muy ynjusta e agraviada por las razones seguientes, como porque vuestra reberençia non tyene ninguna jurediçión para hazer lo que faze, a sy algund poder y facultad tyene de nuestro sancto padre éste sería tan solamente para la reformaçión de los monesterios de los monjes de la horden de Sant Venito deste reyno e no de las monjas ni avadesas, porque destas en el dicho poder e breve no se faze cuento, y en caso que vuestra reberençia poder y facultad tenga, pido que me mande dar treslado del poder y facultad de nuestro muy sancto padre, por do dize tener la dicha jurediçión, tyene; a lo otro, porque en caso que juez desto dicho, alguna hallase dicho, digo que sy en dicha mi parte con vuestra reberençia tyene de litigar ella teme sea muy agraviada y sospecha e reçela que non le ha de hazer justiçia, ansy porque en la manera del proceder que hasta aquí aveys procedido en la reformaçión de los priores y abadesas deste reyno ha seydo executado y de fecho, como porque quiere la renta de los monesterios de las dichas avadesas espeçialmente para su monesterio de Sant Benito de Valladolid, y disolver y deshazer el monesterio de la dicha mi parte segund que se a fecho a otros monesterios deste reyno; e demás desto, porque vuestra reberençia a dicho públicamente que a todas las abadesas deste reyno ha de pribar de sus monesterios, espeçialmente a la dicha mi parte, y las he de fazer quanto mal pueda fasta que salgan de los dichos monesterios y estén en el monesterio de Sant Payo, porque no es su voluntad que aya otros monesterios de monjas en este reyno, salvo éste; y demás desto, vuestra reberençia ha dicho públicamente a la dicha mi parte que renunçie e resyne su monesterio, e sy no lo renunçia, que aunque la vida le cueste se ha de llevar este negoçio al cabo, y asymismo porque Fernando Destrada, el fiscal y el que acusa a la dicha mi parte, es criado e continuo comensal de vuestra reberençia, de manera que por estas razones e por otras, yo en nonbre de la dicha mi parte tengo a vuestra reberençia por muy odioso e sospechoso, e por questo me consta e la 
parte litigante antel juez de quien sospecha o teme que no hará justiçia desde agora segund que mejor puedo e de derecho devo, recuso y he a vuestra reberençia por sospechoso, la qual sospecha juro a Dios que no la pongo maliciosamente, salvo por lo que dicho tengo, e pido ante todas cosas traslado a este artículo del, caso que vuestra reberençia juez se fallare faga lo que derecho ha de hazer, porque la dicha mi parte está presta e aparejada de nonbrar y fazer las diligencias que deve y es obligada; e protesto la nulidad de lo que pretermiso en este artículo se fisyere e lo otro, porque en caso que todo esto logar non oviese, dygo que vuestra reberençia no pudo mandar a la dicha mi parte paresçer ante sy personalmente, ansy por la honestidad de su persona, como porque sería y es enferma y enpedida, mayormente que a las religiosas y monjas como ella es, no le sería lícito ni honesto salir fuera de su monesterio a litigar, andando entre personas legas, quanto más que la venida e acceso a esta dicha cibdad no lo sería en hestado seguro, antes se teme e reçela que vuestra reberençia la mandaría prender e prendería, como ha fecho a otras monjas que agora están en Sant Payo, y como a ella oviera fecho sy oviera podido. Por ende, a vuestra reberençia pido e requiero, que después de pronunçiado sobre el artículo de la jusrisdiçión, en caso que juez se hallare, e pronunçiado primeramente sobre la recusación o a lo menos entretanto me aya por presentado a la citaçión que a la dicha mi parte se faze, e la resçiba por procurador, pues que su venida e acceso no es tuto ni seguro, e sy ansy no lo quisyere fazer, salvo proçeder en este dicho negoçio segund lo tyene començado syn más la dicha mi parte ser oyda, desde agora para entonces tanquam abillat.et somient.? gravaminibus apelo de vuestra reberençia y de todo lo que fasta aquí ha fecho y mandado, y de lo que de aquí adelante fesyere o mandare, por ante nuestro muy sancto padre Alexandro Sexto o para ante sus subcesores de todo fago apelaçión, o para ante quien desta dicha cabsa pueda y deva conosçer, so cuya proteçión e amparo pongo a la dicha avadesa mi parte y a su monesterio, y segund que mejor puedo y de derecho devo pido respuesta y apóstolos, e sy negado me fuere pídolo por testimonio, e a los presentes que dello me sean testigos. 


\section{DOCUMENTO 6}

1498, diciembre, 29 (por el cómputo del Nacimiento). Santiago.

\section{Respuesta del reformador a la recusación hecha por el procurador de la abadesa de Lobanes.}

AHN, Clero, Leg. 7706 (Original).

En la cibdad de Santiago en veynte y nueve días del dicho mes de diziembre del dicho año del Nasçimiento de Nuestro Señor Ihesuchristo de mill y quatroçientos y noventa y nueve, dentro del monesterio de Sant Martin, visto por el dicho señor prior este dicho proçesso por ante mí el dicho escrivano y testigos de yusoescriptos, dixo: Que la recusaçión puesta por el digno Diego Alonso en el dicho nonbre no proçedía asu por aver mandado que paresçiese personalmente la dicha abbadesa, como porque las causas de la dicha recusaçión y sospecha ern notoriamente falsas y no eran tales que de derecho devían ser resçibidas, espeçialmente en causa de visitaçión e reformaçión y declarava no aver lugar la tal recusaçión y que sy nesçesario era se pronunçiava e pronunçió por juez conpetente deste dicho negoçio y mandava yr por el dicho proçeso adelante, y más dixo, que la apelaçión ynterpuesta por el dicho Diego Alonso en el dicho nonbre no avía lugar, ni al dicho señor prior le constava de su poder y aunque lo toviera, que no le avía de resçivir si personalmente no paresçía la dicha abbadessa; y que fasta agora no le avía hecho agravio alguno, y que le denegava y denegó la dicha apelaçión y le dava por respuesta los apóstolos refutatorios y que mandava se siguiese el proçeso en rebeldía fasta tanto que la dicha abbadessa parezca personalmente y a mayor habondamiento mandava que notificase al dicho Diego Alonso que hiziese saber a la dicha su parte que si quería paresçer personalmente, que dende agora la asegurava que durante el pleyto no la prendería ni le haría mal ni dapno alguno, salvo que se quería ynformar della de algunas cosas conplideras a su consçiençia y al bien de su monasterio, y a la visitaçión y reformaçión de aquél, y para tomar su dicho en las cosas contenidas en dicha querella contra ella dada por el dicho fiscal y que estava presto de resçibir los testigos e ynformaçión de su enfermedad e ynpedimento, como quier que le constava lo contrario, pero por más convençión mandava que

«CUADERNOS DE ESTUDIOS GALLEGOS», Tomo XLIX, Fascículo 115, Santiago 2002. 
dentro de terçero día la presentase, y que haría lo que fuese justiçia, y que estava presto por quitar toda sospecha de no sentençiar en este negoçio sin acuerdo de personas de letras y de recta consçiençia, asy en presençia como en rebeldía de la dicha abbadessa. Y que esto dava por respuesta a la dicha recusaçión y apelaçión denegándola como dicho es, y que mostrándose parte el dicho Diego Alonso le mandava y mandó dar los treslados de los poderes que el dicho señor prior tiene sin costa alguna. Testigos que estavan presentes, el bachiller Françisco de Proaño y Pedro de Villarroel y Pero de Sanz, clérigo de la diócesi de Túy.

\section{DOCUMENTO 7}

1499, enero, 2. Santiago.

Respuesta de Sebastián Serrano, en quien delegó Diego Alonso su procuración, a la decisión del reformador del 29 de diciembre de 1498, que le había sido notificada el 1 de enero de 1499.

AHN, Clero, Leg. 7706 (Original).

El dicho Sebastián Serrano en nonbre de la avadesa de Lovanes, respondiendo a este auto a él notificado dixo: que no se apartando de la dicha su apelaçión, que todo lo por el dicho señor prior fecho e mandado era en sí ninguno de derecho, e contra la dicha avadesa su parte muy injusto e agraviado, asy porque su reverençia se pronunciaba por juez no le aviendo notificado ni mostrado el poder que de nuestro muy sancto padre tenía, como por le aver denegado la recusaçión por él ya interpuesta e pronunciado no aver logar, y tanbién por mandar paresçer ante sy personalmente a la dicha avadesa su parte, lo qual de derecho no podía mandar por ser como hera monja e persona que no puede ser conpelida paresçer personalmente, $\mathrm{y}$ tanbién porque el dicho señor prior estava $\mathrm{e}$ está descomulgado, de manera que todo lo por él mandado e sentençiado es en sy ninguno. Por ende, juntando agravio con agravio, pues que no le quería resçibir por procurador, teniendo presentado poder bastante, que agora como de nuevo apelava e apeló para dónde e ante quién apelado tenía, e que lo pedía por testimonio. Y ansymesmo pedío que por quanto 
ante Jácome Yanes, notario, y ante Ochoa Ybáñes avían pasado çiertas petiçiones, y ambas que las pasasen ante el dicho notario e las posyese en el proçeso.

\section{DOCUMENTO 8}

1499, enero, 15. Santiago.

Petición del fiscal al reformador para que diese por concluído el pleito contra la abadesa de Lobanes, declarándola en rebeldía.

AHN, Clero, Leg. 7706 (Original, del registro notarial).

Rdo. señor y devoto padre: Fernando de Estrada, promotor fiscal de la dicha horden de Sant Benito, paresco ante vuestra merced e digo que bien sabe el pleito e cabsa que yo en el dicho nonbre he e tracto en rebeldía con doña Ynés de Senabria, abbadesa de Sant Pedro de Lobanes, la qual nunca ha paresçido ni paresçe personalmente segund le fue mandado y por mí le fueron acusadas las rebeldías y después han seydo pasados muchos términos y todavía no ha paresçido personalmente segund dicho es. Por ende, pido e suplico a vuestra reverençia que en su absençia e rebeldía aya este dicho pleito por concluso, para lo qual su noble ofiçio ynploro e las costas pido e protesto.

\section{DOCUMENTO 9}

1499, junio, 8 .

Acta de visita y reforma del monasterio de Lobanes, hecha por el reformador el 8 de junio de 1499.

AHN, Clero, Leg. 7706 (Original).

En el monesterio de Sant Pedro de Lobanes, del orden de Sant Benito, sito en la diócesi de Orense, a ocho días del mes de junio, año del 
Nasçimiento de Nuestro Señor Salvador Ihesuchristo de mill é quatroçientos y noventa y nueve años, en presençia de mí el notario público y testigos ynfraescriptos, el reverendo señor don fray Rodrigo de Valençia, prior del monesterio de Sant Benito de Valladolid, juez apostólico y reformador general de la dicha orden de Sant Benito en los reynos de Castilla e Galizia e probinçia del Bierzo, visitando personalmente el dicho monesterio de Sant Pedro de Lobanes y entendiendo en la visitaçión y reformaçión dél, y estando ausente doña Ynés de Sanabria, abbadesa de dicho monesterio, ante todas las cosas presentó e notificó las bullas e poderes appostólicos que del nuestro muy sancto padre tenía. Asy presentados e notificados dixo: que por quanto a pedimiento del procurador e síndico general de la dicha orden de Sant Benito y promotor fiscal della avía proçedido contra la dicha doña Ynés de Sanabria, abbadesa del dicho monesterio, e hazía su processo hordinario en forma, por los excesos e delictos que el dicho syndico dixo ella aver cometido, e sobre las otras causa e razones en el dicho processo del dicho pleyto contenidas, que non anullando el dicho proceso ni perjudicando a los autos de aquél, antes en confirmaçión e aprobaçión suya e para más sustançia e validaçión de aquél, y para mejor cumplir lo a él cometido e mandado a él por el nuestro muy sancto padre por sus bullas e breves apostólicos en que le mandava hazer la dicha visitaçión e que viniese personalmente a las casas e monesterios de la dicha orden de Sant Benito, que el venía como vino personalmente en presençia de mí el dicho escrivano a la dicha casa e monesterio de Sant Pedro de Lobanes para la visitar e reformar e inquirir in capitibus et in membris segund el thenor y forma de los dichos poderes y de lo al él contenido y mandado, y que las cosas que en la dicha visitaçión e ynquisiçión hallase meresçedoras de enmendaçión, pugnaçión e castigo, que las proveería conforme a justiçia e a la regla de señor Sant Benito al tenor de lo a él cometido e mandado. E que por quanto para la dicha visitaçión, reformaçión e ynquisiçión que así entendía de hazer, él avía mandado aperçivir a la dicha abbadessa e a todos los abbades e abbadessas e priores de la dicha orden de Sant Benito deste reyno de Galizia, e les avía asegurado por su carta de seguro y de los señores oydores e alcaldes mayores de sus altezas que en el dicho reyno de Galizia residen, e por quanto en el dicho monesterio no estava la dicha abbadessa ni otra monja alguna, y se avía ausentado e huydo dél y no se podía hallar ni sabía casa ni morada çierta donde la dicha abbadesa estoviese, que mandaba e man-

«CUADERNOS DE ESTUDIOS GALLEGOS», Tomo XLIX, Fascículo 115, Santiago 2002. 
dó el dicho notario, que en rebeldía de la dicha abbadessa notificase a las puertas de yglesia e monesterio cómo él era venido personalmente para hazer la dicha visitaçión e ynquisiçión e que so las penas de excomunión e pribaçión que estavan puestas, le mandava e mandó que paresçiese ante él personalmente en el dicho monesterio de Sant Pedro de Lobanes para la dicha visitaçión, reformaçión e ynquisiçión e para le tomar su dicho, juramento e declaraçión e para la visitar e ynquirir al thenor y forma de los dichos poderes apostólicos, los quales asymesmo le mandava e mandó notificar a las dichas puertas de la dicha yglesia, e que sy para la dicha visitaçión e ynquisiçión que asy avía de hazer menester fuese citaçión alguna en principio della o susçesive, e para todos los otros autos que en ella se oviesen de hazer fasta la sentençia o sentençias, provisión o provisiones e mandamientos que se oviesen de dar o de hazer, que mandava e mandó que fuese çitada la dicha abbadessa en la manera que dicha es, e que desde agora la emplaçava e çitava para todo ello. E le mandava e mandó que de oy en terçio día a la ora de la terçia paresçiese ante él personalmente en el dicho monesterio de Sant Pedro de Lobanes, segund dicho es, para lo susodicho, el qual dicho término le señalava easeñaló por perentorio, con aperçibimiento que le hazía, que paresçiendo al dicho término segund dicho es la oyría e guardaría su justiçia, en otra manera el dicho término pasado, en su rebeldía e contumaçia proçedería a reçepçión de testigos e a todos los otros auctos de visitaçión e ynquisiçión fasta la sentençia definitiva ynclusive y execuçión della, para los quales auctos e cada uno dellos desde agora la çitava y emplazava e mandava çitar y emplazar, segund dicho es, perentoriamente, e le aseñalava y aseñaló el dicho monesterio donde le fuesen fechos e notificados, y que como quiera que de derecho por virtud de la dicha visitaçión e ynformaçión podiese dar sentencia alguna, que protestava e protestó que no parase perjuizio al dicho proçeso hordinario, antes que todo ello o cada uno por sí valiese e fuese para efecto de reformar el dicho monesterio e abbadessa, e la pugnyr, enmendar e castigar e protegir e provar si menester fuese, y que esto mandava dezía e hazía en la mejor forma e manera que podía e con derecho debía, e que sy algun themor o reçelo la dicha abbadessa tenía de paresçer ante él personalmente, que como quiera que antes de agora la tenía segurada segund dicho es, porque a mayor habundamiento e por más justificaçión le asegurava e aseguró que contra razón e derecho no sería presa ni detenida ni hecho otro mal dapno alguno en su persona e 
bienes. Testigos que estavan presentes fray Pedro de Çamora e fray Rodrigo de Peñafiel, monjes profesos dela dicha orden y el liçençiado Alonso de Pomareda, corregidor de la villa de Sarria y Diego Velón, merino de Samos, y Fernando Mourin e Luys de Ribadeo e Juan del Freixo e Lope Osorio e Alfonso Vázquez, criados de Fernando de Camba e otros.

(Firmado:) Gonçalo de Nájera, notario.

E después de lo susodicho yncontinente el dicho señor prior reformador visitó las cosas syguientes:

\section{Altares}

Primeramente, visitó el altar mayor, cuya vocaçión es Sant Pedro. Estava en él uan ara con unos corporales e çinco sábanas e una cruz de metal con unas piedras de vidrio.

Visitó el altar de la mano derecha, cuya vocaçión es (en blanco). Estava en él una sábana.

Visitó el altar de la mano siniestra, cuya vocaçión es de Santa Catherina. Estava en él una sábana.

\section{Vestimentas}

Visitó las vestimentas, en que halló quatro vestimentas de lienço con sus aparejos. Dos sábanas razonables y otras sábanas viejas.

\section{Libros}

Visitó los libros y halló los siguientes: Un ofiçiero dominical de pergamino. Un raçionero de pergamino. Un evangelistero y epistolero de pergamino, en un volumen todo. Dos leçionarios de pergamino. Un evangelistero e un libro de exorçismos.

Halló unas vinajeras de estaño y un ençensario de cobre.

Visitó el choro y no halló syllas en él ni las avía.

Visitó más dos camarillas y no avía en ellas cosa alguna, salvo una cama de madera con paja, en la una.

Halló en otra cámara una arca e dos pallizos de echar pan e un dorno (sic) e una cubeta e una artesa en una casa del horno.

Estava dentro de la yglesia una tulla. E de cómo asy lo halló todo y visitó y halló ausentada a la dicha abbadessa y llevado lo que tenía, el dicho señor prior lo pidió por testimonio. Testigos, los dichos.

«CUADERNOS DE ESTUDIOS GALLEGOS», Tomo XLIX, Fascículo 115, Santiago 2002. 


\section{DOCUMENTO 10}

1499, junio, 10. Lobanes.

Pedro de Villarroel, fiscal substituto pide al reformador que declare en rebeldía a la abadesa de Lobanes y dé por concluído el pleito y lo sentencie, como lo hizo el reformador.

AHN, Clero, Leg. 7706. (Original; registro notarial).

En el pleyto y causa que ante nos pende entre el procurador y promotor fiscal de la horden de Sant Benito de la una parte e doña Ynés de Sanabria, abbadesa del monesterio de Sant Pedro de Lobanes en su absençia e rebeldía de la otra, sobre las causas e razones en el proçeso del dicho pleito contenidas: Fallamos, que para más clara y mejor expediçión deste dicho pleito e cabsa que devemos resçibir e resçibimos a amas las dichas partes conjuntamente a la prueva e a cada una dellas de todo lo por ellas ante nos dicho e alegado, e a todo aquello que provar devan e provado les aprovechara, salvo jure ynpertinentium et non amittendose (sic) para la qual prueva fazerla traer e presentar ante nos, les mandamos e asygnamos término de nueve días primeros siguientes, los quales corran e se cuenten con oy, día de la data desta nuestra sentençia. E este mesmo plazo damos e asygnamos a amas las dichas partes e a cada una dellas para que parescan ante nos a ver, presentar, jurar e conosçer los testigos e provanças e escripturas que la una parte presentare contra la otra e la otra contra la otra sy quisyere, e para hacer juramento de calupnia. Asy nuestra carta de reçeptoría oviere visto, nonbrando los lugares mandárgela hemos dar aquélla que con derecho devamos y por esta nuestra sentençia asy lo pronunçiamos, setençiamos y mandamos en estos escriptos e por ellos.

(Firmado:) F.R.V.S.B. prior et apostolicus refformator. 


\section{DOCUMENTO 11}

1499, junio, 10. Lobanes.

Interrogatorio por el que fueron preguntados los testigos Diego García, Ruy de Custoya, Alfonso de Soutodevilla, Lorenzo Pajariño y Juan de Paradela, vecinos y moradores del coto de Lobanes.

AHN, Clero, Leg. 7706. (Original; registro notarial).

E lo que los dichos testigos e cada uno dellos depusieron y declararon secreta y apartadamente cada uno por sí en presencia del dicho señor prior y por ante mí el dicho notario, es lo que adelante del ynterrogatorio que el dicho procurador fiscal sustituto presentó por donde el dicho señor prior les preguntó se sygue:

Las preguntas por donde han de ser preguntados los testigos por mí Pedro de Villarroel, procurador e promotor fiscal sustituto de la horden de Sant Benito que son e fueren presentados en el pleito e cabsa que en el dicho nonbre he e tracto con doña Ynés de Senabria, abadesa del monesterio de Lobanes, son las syguientes e por cada una dellas:

Primeramente. Sy conosçen e han notiçia de la dicha Ynés de Senabria, abbadesa del dicho monesterio de Sant Pedro de Lobanes, e sy es monja profesa de la dicha horden de Sant Benito, e sy saben quel dicho monesterio es de la dicha horden de Sant Benito.

$2^{\mathrm{a}}$. Yten, sy saben que vieron o oyeron dezir de qué forma e manera e con qué título la dicha Ynés de Senabria ovo la dicha abbadía o porqué cabsa, razón o derecho ha thenido e posseydo el dicho monesterio e abbadía.

$3^{\mathrm{a}}$. Yten, sy saben e conoçen que la dicha abbadesa aya tenido e tenga amigos e rufianes pública o secretamente, asy en el dicho monesterio de Sant Pedro de Lobanes, como en otras partes e logares fuera de dicho monesterio, clérigos o casados, e dellos tenga fijos o fijas; digan e declaren lo que cerca desto saben, que lo vieron o oyeron dezir.

$4^{\mathrm{a}}$. Yten, sy saben e conosçen que la dicha abbadesa es muger ydiota syn letras, e que sabe muy poco de lo que al ofiçio divino pertenesçe, y para regir e administrar el dicho monesterio.

$5^{\mathrm{a}}$. Yten, sy saben e conosçen que la dicha abbadesa aya muchas vezes ydo a boddas e a batisterios e ferias e misas nuevas, deshonesta- 
mente, como muger seglar, e las ha fecho e consentido hazer en el dicho monesterio.

$6^{\text {a }}$. Yten, sy saben e conosçen que la dicha abbadesa aya seydo e es muy lapidadora e gastadora de los bienes e rentas del dicho monesterio, e los aya gastado con sus amigos e rufianes e con los fijos e fijas e criados que tenía y no los gastava en reparos y provechos del dicho monesterio, enagenándolos e aforándolos malamente, en grand engaño e fraude del dicho monesterio.

$7^{\mathrm{a}}$. Yten, sy saben e conosçen que la dicha abbadesa e monjas que con ella estavan non guardavan la regla de Sant Benito, ni se confesavan, ni resçibían los sacramentos, como eran obligadas, a sus tiempos, e que comían carne e vestían lienço e dormían en sávanas, e non guardavan sylençio, ni rezavan ni hazyan el ofiçio divino, como eran obligadas, mas antes estavan de continuo fuera de dicho monesterio por los lugares, plaças e mercados, deshonestamente.

$8^{\mathrm{a}}$. Yten, sy saben e conosçen que la dicha abbadesa e monjas andavan a caça con los dichos sus amigos por los montes, a pie e a cavallo, con perros e galgos e aves, muy disolutamente.

$9^{a}$. Yten, sy saben e conosçen que de todo lo susodicho e de cada una cosa e parte dello sea e es asy pública boz e fama, en el dicho monesterio e su cotto e comarca.

Yten, de ofiçio de vuestra reverençia el qual para ello ynploro le pido e suplico en el dicho nonbre les mande fazer e faga las otras preguntas al caso tocantes e pertenesçientes.

\section{DOCUMENTO 12}

1499, junio, 10. Lobanes.

\section{Deposición de los testigos Pedro Geadalván y Arias Mosquera.}

AHN, Clero, Leg. 7706. (Original; registro notarial).

El dicho Pero Geadalvan, testigo susodicho jurado y preguntado por el dicho señor prior por las preguntas del dicho ynterrogatorio y por cada una dellas dixo queya otra vez le avía tomado juramento sobre este 
mismo negoçio y avía depuesto e declarado lo que çerca dello sabía por ante Fernando Martínez de Sancta Gadea, notario, y que agora aquello mesmo dezía y se retificava e retificó e se afirmava e afirmó en ello, e que sy nesçesario era lo dezía e dixo de nuevo una y dos y más vezes, segund y de forma y manera que por ante el dicho notario lo avía dicho y declarado.

Fue preguntado por el dicho señor prior sy sabía que la dicha abbadessa se avía ausentado del dicho monesterio por no ser visitada ni reformada y si llevó todo lo que en el dicho monesterio estava. Dixo que lo que desto sabe es que vio ausentarse la dicha abbadessa del dicho monesterio, y que oyó dezir que avía llevado todo quanto en el dicho monesterio la dicha abbadessa tenía y que esto es lo que sabe del dicho negoçio, y lo dize una y dos y más vezes quantas nesçesarias fueren, y firmólo de su nonbre.

El dicho Aries Mosquera, testigo jurado y preguntado por el dicho señor prior por las preguntas del dicho ynterrogatorio dixo que ya otra vez le avía tomado juramento por ante Fernando Martínez de Sancta Gadea, notario, sobre este mismo negoçio, y avía dicho y declarado lo que çerca dello sabía, que agora aquello mismo dezía e se retificava e retificó e afirmó en ello, y sy nesçesario era lo dezía e se retificara e retificó e afirmó en ello, y sy nesçesario era lo dezía e dixo de nuevo una y dos y más vezes y quantas nesçesarias fuesen segund y de manera que por ante el dicho notario lo avía depuesto y declarado.

Fue preguntado más por el dicho señor prior si sabía por qué la dicha abbadessa se avía ausentado del dicho monesterio por no ser visitada ni reformada y avía llevado todo lo que en el dicho monesterio tenía, dixo: que lo que sabe es que oyó dezir que la dicha abbadesa se avía ausentado del dicho monesterio con lo que tenía por no esperar al dicho señor prior de Sant Benito y que después éste que depone fue en persona al dicho monesterio y no la halló allí, e que es asy pública voz e fama en dicha tierra e comarca del dicho monesterio.

Fue preguntado más, sy sabía de qué manera fue puesta por abbadessa del dicho monesterio la dicha doña Ynés de Sanabria. Dixo que sabe que Sancha Rodríguez, abbadesa que fue del dicho monesterio se salió dél por su propia voluntad como muger de mal seso y mal gobernada de juizio, y se fue a casa de su madre y sus parientes e que dexó asy solo el dicho monesterio syn monja ni otra persona alguna, e que después Fernando de 
Canba traxo a la dicha Ynés de Sanabria al dicho monesterio por abbadessa. E que oyó dezir que le avía hecho título della. Preguntado sy sabía que se avía hecho algún proceso contra la dicha Sancha Rodríguez, por donde fuese privada e quitada de la dicha abbadía dixo que no lo sabe ni lo oyó dezir, e que eso es lo que sabe sobre el dicho negoçio.

\section{DOCUMENTO 13}

1499, junio, 28. Santiago

Citación de la abadesa de Lobanes para que comparezca personalmente a oir la sentencia del pleito hecho contra ella.

AHN, Clero, Leg. 7706. (Original; registro notarial).

Nos, don fray Rodrigo de Valençia, prior del monesterio de Sant Benito de Valladolid, juez apostólico y reformador general de la dicha orden de Sant Benito, en los reynos de Castilla e Galizia e provinçia del Vierzo, hazemos saber a vos doña Ynés de Sanabria, abbadessa que os dezís del monesterio de Sant Pedro de Lobanes, como bien sabéis el pleito y causa que el procurador y promotor fiscal de la dicha orden de Sant Benito en el dicho nonbre ante nos con vos tracta sobre el dicho monesterio e sobre las otras causas e razones en el dicho proceso contenudas e asimesmo el proceso de visitaçión e ynquisiçión que de nuestro ofiçio por virtud de los dichos poderes apostólicos contra voz hezimos quando personalmente fuímos a visitar el dicho monesterio, en los quales dichos procesos fuistes citada e mandada citar antes que al dicho monesterio fuésemos, y después que a él fuímos asy por en el dicho proceso del dicho fiscal como por el de visitaçión e ynquisiçión susodicha, para que en el dicho monesterio de Lobanes paresçiésedes personalmente y vos nunca paresçistes, antes vos ausentastes del dicho monesterio e andáys fuera dél fecha apóstata y descomulgada fuera de vuestra orden e religión, e después que del dicho monesterio partimos asimesmo vos citamos que viniésedes en seguimiento del dciho negoçio e pleyto del dicho fiscal e de visitaçión e ynquisiçión ante nos en el monesterio de Sant Martín de la cibdad de Sanctiago, donde al presente 
estamos e residimos entendiendo en cosas tocantes a la dicha reformaçión e vos dimos harto término en que pudiésedes paresçer y vos citamos para todos los autos del dicho pleyto fasta la sentençia definitiva, segund que más largamente pasó por el notario de la causa y vos todavía no pareçistes, aunque vos ovimos asegurado, y en vuestra ausençia y rebeldía e que vindos por contumaz e rebelde ovimos el dicho pleyto por concluso. E comoquier que como dicho es fuistes citada para todos los auctos de los dichos procesos y de la dicha causa, y para la sentençia definitiva, y vos fue aseñalado el dicho monesterio de Sant Martín para todos ellos, y pudiéramos dar e pronunçiar la dicha sentençia definitiva, pues los dichos procesos teníamos vistos y estavan conclusos, la qual por el dicho fiscal nos fue pedido pronunçiásemos y diésemos segund que por el derecho y por la dicha regla de Sant Benito hallásemos, pero a mayor habundamiento e para más convençión e justificaçión de los dichos procesos, acordamos de vos citar otra vez para oyr la dicha sentençia definitiva. E mandamos dar e dimos esta nuestra carta citaçión y enplazo para vos en la forma siguiente, por la qual en vitud de santa ovediençia y so pena de excomunión mayor vos mandamos y exortamos primero, segundo, terçio e perentorio, asy que del día que esta nuestra carta vos fuere notificada en vuestra persona pudiendo ser avida, sy no ante las puertas del dicho monesterio de Sant Pedro de Lobanes, la qual notificaçión mandamos agora asy como sy en vuestra persona fuese notificada, por quanto estamos ynformado e nos consta por la dicha visitaçión e ynquisición que andáys hecha apóstata y fuera del dicho monesterio, e porque no sabemos lugar çierto ni morada donde estays y residís para vos poder notificar en vuestra persona, fasta quatro días primeros siguientes, los quales vos damos e asygnamos por término perentorio, y en el postrimero dellos a la ora de las vísperas, no syendo día feriado, y sy lo fuere, para otro día siguiente que feriado no sea a la ora de vísperas, parezcáis ante nos personalmente en el dicho monesterio de Sant Martín, donde primero fuistes citada, para oyr la dicha sentençia definitiva que por virtud de los dichos procesos diéremos y pronunciáremos; para la qual oyr desde agora para entonçes vos citamos, llamamos y emplazamos perentoriamente e vos aseñalamos este dicho monesterio de Sant Martín donde vos sea notificada, con apercebimiento que vos fazemos, que si no paresçierdes como dicho es, que en vuestra absençia y rebeldía no enbargante, avida por presençia,

«CUADERNOS DE ESTUDIOS GALLEGOS», Tomo XLIX, Fascículo 115, Santiago 2002. 
la daremos e pronunçiaremos, segund que hallaremos por derecho y por la dicha regla de Sant Benito, y la mandaremos executar y llebar a debido efecto sin vos más çitar ni llamar ni atender para ello, e sin vos la notificar. E porque más seguramente podáys venir a oyr la dicha sentençia al dicho monesterio para el dicho día, como quiera que ya por muchas vezes vos hemos asegurado, pero para mayor habundamiento y por más justificaçión, por el thenor de la presente vos aseguramos que por fuerça ni contra razón e derecho no seréys presa ni detenida, ni vos será fecho otro mal y dapno en vuestra persona e bienes. En testimonio de lo qual la mandamos dar e dimos firmada de nuestro nonbre e sellada con nuestro sello e firmada del notario ynfraescripto. Dada en el dicho monesterio de Sant Martín de Sanctiago, a veynte e ocho días del mes de junio de mill y quatroçientos y noventa y nueve años.

(Firmado:) F.R.V.S.B. prior et appt. rrefformator. Por madado del dicho señor prior reformador. Gonçalo de Nájera, notario.

\section{DOCUMENTO 14}

1499, julio, 8. Santiago.

Sentencia definitiva contra la abadesa de Lobanes, dada por el reformador y juez apostólico.

AHN, Clero, Leg. 7702. (Original).

Por nos, don fray Rodrigo de Valençia, prior del monesterio de Sant Benito de la villa de Valldolid, juez apostólico y general reformador de toda la horden de Sant Benito en los reynos de Castilla e Galizia por auctoridad de nuestro muy sancto padre Alexandro Sexto, moderno, e vista çierta denunçiaçión e querella dada por el procurador y promotor fiscal e syndico general de la dicha horden contra doña Ynés de Senabria, abbadessa que se dize del monesterio de Sant Pedro de Lobanes, e vistas las probanças ante nos por el dicho fiscal presentadas sobre sus delictos y excessos, e sobre su ynabilidad e ignorançia de la regla e modo de vivir, e vista la visytaçión e ynquisiçión por nos fecha contra la dicha doña Ynés de Sanabria, e vista la appostasía e rebelión della e visto cómo la dicha 
abbadessa no tiene título alguno a la dicha abbadía de Lobanes, e sobre las otras causas e razones en los dichos procesos del dicho fiscal e de visytaçión e ynquisiçión contenidos, avido sobre todo nuestro acuerdo e deliberaçión e puestos aquel eterno Dios ante nuestros ojos:

Fallamos, que atentos los auctos e deméritso de los dichos processos, que la dicha doña Ynés de Senabria no tiene título ni derecho alguno a la dicha abbadía e monesterio e que por tal devemos pronunçiar e pronunçiamos e que sy algund título o derecho ha tenido o tiene, que ella ha quebrantado la castidad y obediençia que son de esencia de nuestra regla e religión, e que ha vivido muy dissolutamente non guardando la dicha regla, e que ha seydo destruydora e dilapidadora de los bienes e rentas del dicho monesterio de Sant Pedro de Lobanes, e que ha cometido otros crímenes y exçessos dignos de grand pugniçión e castigo, por lo qual la dicha doña Ynés de Senabria es digna de privaçión de qualquier derecho, propiedad o possessión que a la dicha abbadía e monesterio tenga, e de otras penas en derecho e en la dicha regla de Sant Benito establesçidas. Por ende, que devemos privar, amover e quitar, privamos, amovemos e quitamos a la dicha doña Ynés de Senabria de qualquier derecho, propiedad e possessión que al dicho monesterio e abbadía tenga, e quel dicho monesterio e la dicha doña Ynés de Senabria deven ser reduzidos e puestos en verdadera observançia. E mandamos a la dicha doña Ynés de Senabria, en virtud de santa obediençia y so pena de excomunión mayor, que se vaya al monesterio de Sant Payo de Antealtares de la dicha cibdad de Sanctiago dentro de los veynte días primeros syguientes del día de la data desta nuestra sentençia, que es monesterio reformado, donde esté e syrva a Dios y guarde la dicha regla, adónde le mandaremos proveer de todas las cosas a ella nesçessarias, y que non salga del dicho monesterio de Sant Payo, so pena de ser avida por apóstata y descomulgada, y condenámosla más en las costas derechamente fechas en la prosecuçión desta cabsa, la tasaçión de las quales en nos reservamos y por esta nuestra sentençia diffinitiva juzgado, asy lo pronunçiamos, sentençiamos, mandamos pro tribunali sedendo en estos escriptos y por ellos.

(Firmado:) F.R.S.B. prior et apostolicus reformator.

Dada, rezada e pronunçiada fue esta dicha sentençia por el dicho señor prior reformador, que la firmó de su nonbre, dentro del monesterio de Sant Martín de la cibdad de Sanctiago, a ocho días del mes de jullio de 
mill e quatroçientos e noventa y nueve años, a la hora de vísperas, sedendo pro tribunali. Testigos que estavan presentes: fray Pedro de Maçuelo, presidente del monesterio de Sant Pedro de Eslonça, e fray Gonçalo de Peñalva, prior que fue del monesterio de Sant Pedro de Foras e Alvaro Jenero, notario e Alfonso del Riego, azavachero, vezinos de dicha cibdad, e Gómez de Laguna, capellán del monesterio de Ponbeyro, e Alvaro de la Trinidad, y presente el dicho Fernando de Estrada, fiscal. E luego yncontinente, yo, el dicho notario, la notifiqué en rebeldía de la dicha doña Ynés de Sanabria en el dicho lugar donde fue dada y pronunçiada, y donde fue citada, y aseñalado lugar para la dar e oyr, e para donde le fuese notificada, en presençia de los dichos testigos.

(Firmado:) Gonçalo de Nájera, notario.

\section{DOCUMENTO 15}

1499, julio, 9. Santiago.

\section{A petición del fiscal, el reformador manda ejecutar la sentencia dada contra la abadesa de Lobanes y tomar posesión de este su monasterio.}

AHN, Clero, Leg. 7702. (Original; registro notarial).

E después de lo susodicho, en el dicho monesterio de Sant Martín, a nueve días del dicho mes e año sobredichos ante el dicho señor prior, el dicho Fernando de Estrada, fiscal, en el dicho nonbre, dixo: que por quanto su reverençia avía dado e pronunçiado la dicha sentençia en favor de la dicha orden e observançia e suyo en su nonbre, e avía seydo notificada en rebeldía de la dicha doña Ynés de Sanabria en el lugar aseñalado para la oyr donde estava citada, la qual por ella ni por otro en su nonbre no avía seydo apelada, y puesto que la apelara, que no avía lugar a apelaçión, asy porque avía seydo justamente dada e ser sobre correpçión, e porque sus delictos eran muy notorios, como por virtud de la cláusura oppositione remota en la dicha bulla e vreve appostólico contenida, que el dicho señor prior tenía, por donde proçedía que pedía e pidió al dicho señor prior le mandase dar su carta fuese llevada a pura e devida execuçión y con effecto, y le mandase en el dicho nonbre po- 
ner y apoderar en la posesión real e actual seu quasi del dicho monesterio con todo lo a él anexo y pertenesçiente, y acudir con todos los fructos y rentas y eclesyásticas derechuras, y otros qualesquier cosas a él devidas y pertenesçientes, para que por su reverençia fuese reformado dicho monesterio y puesto y reduzido en observançia regular al thenor y forma de sus poderes. El dicho señor prior dixo que lo oya e que mandava e mandó dar su carta executoria para ello en forma debida. Testigos que estavan presentes fray Pedro de Maçuelo e fray Vernaldino de la Torre e fray Pedro de Çamora, monjes profesos de la dicha orden, e Luys de Ribadeo, e otros.

\section{DOCUMENTO 16}

1499, julio, 19. Santiago.

Apelación de la dicha sentencia por parte del procurador de la abadesa de Lobanes.

AHN, Clero, Leg. 7727. (Original).

Reverendo señor don fray Rodrigo de Valençia, prior del monesterio de Sant Venito de Valladolid, yo, Diego Alonso, en nombre de doña Ynés de Sanabria, abadesa del monesterio de Lobanes, digo que es venido nuevamente a mi noticia en cómo vuestra reverençia diz que secreta e ascondidamente ha dado vuestra sentençia contra la dicha mi parte, en que la privó del dicho monesterio e dynidad, e ansymismo dio carta executoria de su sentençia, e que de fecho la executó segund que más largamente en la sentençia e proceso e abtos dello que sobre esto han pasado se contiene, cuyo thenor avido aquí por expreso e repetido a que me refiero, digo la dicha sentençia como la execuçión por virtud della fecha, ser ninguna o de alguna contra la dicha mi parte, muy ynjusta e agraviada por todas las cabsas e razones que dello junto con lo procesado se pueden e deven colegyr, las quales he aquí por expresadas, e por las syguientes; lo uno por se dar la dicha sentençia a pedimento de no parte, exageradamente, syn conosçimiento de cabsa, e syn que se fiziese proceso, alomenos tal, que estoviese en estado para que la dicha sentençia

«CUADERNOS DE ESTUDIOS GALLEGOS», Tomo XLIX, Fascículo 115, Santiago 2002. 
se podiese dar e pronunçiar; lo otro porque cuanto a la dicha mi parte ni a mí en su nonbre constó del poder que vuestra reverençia tobiese para proçeder tan exarato como fasta aquí ha proçedido; lo otro porque presentándome yo en nonbre de la dicha mi parte e pidiendo copia e treslado del proceso que contra ella se fazía, vuestra reverençia me deviera de oyr e non fazer proceso en reveldía contra ella, pues que seyendo como es monja non podía ser conpelida a paresçer personalmente en juizio. Lo otro, porque pues vuestra reverençia estava recusado en este dicho pleito e negoçio, non havya de dar sentençia fasta tanto que la dicha suspetha primeramente se conosçiese en forma de derecho, o alomenos non executar, antes otorgar a la dicha mi parte la apelaçión que avía fecho. Lo otro, porque sy vuestra reverençia para privar e condenar a la dicha mi parte ubo consideraçión a que ella no estuvo en su monesterio al tienpo que la yba a vysitar, digo que sy ella se absentó fue por justo themor que de vos tenía, porque no la prendiésedes como a otras abadesas e monjas que en Sant Payo están aveys fecho. Lo otro, porque puesto que la dicha mi parte fuera sentençiada non devya vuestra reverençia mandar executarla fasta tanto que se le guardaran sus términos, que apelaría e seguir su apelaçión por las quales razones e por cada una dellas e por todas las por mí dichas e alegadas, e por las que entiendo dezir e alegar en prosecuçión desta cabsa, apelo de la dicha sentençia e de su efecto e de la dicha carta executoria, e de todo lo por vuestra reverençia en este dicho negoçio mandado e executado, por antel nuestro muy sancto padre Alexandro Sesto e por ante sus abdytores de Rota e Sacro Palaçio o por ante quien desta dicha cabsa pueda e deva conosçer, so cuya protección e amparo pongo a la dicha abadesa mi parte e a su monesterio e bienes, pido resposta a apelos sepe sepius sepissimae instanter instançius instantisime y tantas quantas vezes puedo e de derecho devo protesto de no renunçiar a esta dicha mi apelaçión por abto o abtos que ante vuestra reverençia fagan o digan, antes la seguyr e proseguir ante quién y cómo devo, e pídolo por testimonio, y a los presentes que dello sean testigos. 


\section{DOCUMENTO 17}

1498, diciembre, 4. Santiago.

Citación del reformador a la abadesa de Dozón y Ansemil para que comparezca a responder de las acusaciones presentadas por el fiscal de la Orden de San Benito en Galicia.

AHN, Clero, Leg. 7711. (Original).

E nos don fray Rodrigo de Valençia, prior del monesterio de Sant Benito de Valladolid, juez appostólico e reformador general de toda la horden de Sant Benito en los reynos de Castilla, Galizia con la provinçia del Bierzo, dado e deputado por el nuestro muy sancto padre Alexandro Sexto moderno a supplicaçión del rey e de la reyna nuestros señores, segund se contiene más largamente en los poderes e bullas apostólicas que tenemos, las quales no mandamos aquí ynxerir por su grand prolixidad y por ser muy notorias en los dichos reynos, y porque asymesmo fueron notificadas a todos los abbades e priores de la dicha horden de Sant Benito deste dicho reyno en el capítulo general que en el monesterio de Sant Martín de la cibdad de Sanctiago se hizo, pero a mayor abondamiento, mandamos al notario por ante quien esta nuestra carta fuere notificada, que dé copia e traslado dellas por salario conpetente al que las pidiere. Hazemos saber a vos doña Ysabel de Ulloa, abbadesa de los monesterios de Sant Pedro de Doçón e Ansemil, que Fernando de Estrada en nonbre e como promotor fiscal de la dicha horden de Sant Benito, paresçió ante nos e se nos querelló de vos, e nos fizo relación diziendo que después que vos la dicha doña Ysabel de Ulloa soys abbadesa de los dichos monesterios, que avéys tenido la horden e hábito de nuestro padre Sant Benito e seydo monja profesa, cómo non avéys guardado la regla e constituçiones de la dicha horden de Sant Benito e avéys fecho e cometido muchos delictos e excessos dignos de gran pugnaçión e castigo, en grand offensa de Dios nuestro señor e en grad ynfamia e en muy mal exienplo de todas las otras religiosas de la dicha horden, andando muchas veces en bodas y baptisterios e en ferias muy desonestamente e contra las dichas regla e constituçiones de nuestro padre Sant Benito. Demás desto, dize que avéys seydo e soys muy

«CUADERNOS DE ESTUDIOS GALLEGOS», Tomo XLIX, Fascículo 115, Santiago 2002. 
destruydora e dissipadora de los bienes e rentas de los dichos monesterios de Sant Pedro de Doçón e de Ansemil, dándolos e enagenándolos en cosas profanas, hasyendo dellos fueros a quien queríades e por bien teníades en casos prohibidos, e que demás desto, vos, la dicha abbadesa, juntamente con las otras religiosas de los dichos monesterios contra la dicha regla de nuestro padre Sant Benito e contra las constituçiones della, continuamente avéys comido carne e vestido camisas de lino, e asymesmo echado en vuestras camas sávanas de lienço, e que asymesmo salíades de los dichos monesterios para hablar con quantos queríades e non bibíades en clausura e comunidad por lo qual dixo que érades meresçedora de grandes penas, e nos pidió, que aviendo la relaçión por él susofecha por verdadera o tanta parte della que baste para fundamento de su intençión, le hizyésemos cerca dello entero cunplimiento de justiçia e condepnásemos a vos, la dicha abbadesa, en las mayores penas que por derecho e por las constituçiones e regla de dicho nuestro padre Sant Benito hallásemos que meresçíades, e vos condepnásemos más a privaçión de las dichas abbdías e de la asministraçión de aquéllas, e procediésemos contra vos por todo rigor de derecho, de manera que a vos fuese castigo e a las otras religiosas enxienplo, segund que esto e otras cosas más largamente se contiene en la dicha su querella e pedimento, e para en prueva de su yntençión presentó ante nos çierta perquisa e ynformaçión de testigos, lo qual todo por nos visto, como quiera que pudiéramos proçeder por todo rigor de derecho e censura eclesyástica, pero por más convençéros e por mayor justificaçión, mandámosle dar e dimos esta carta para vos en la manera syguiente. Por la qual en virtud de sancta obediençia e so pena de excomunión mayor auctoritate appostolica de que en esta parte usamos, trina canonica monitione previsa, vos eshortamos, requerimos e mandamos que del día que esta nuestra carta vos fuere notificada, pudiendo ser avida, synon ante las puertas de qualquiera de los dichos monesterios de Sant Pedro de Doçón o de Ansemil, seyendo en ellas fixo su treslado, firmado e sygnado de escrivano público, disyéndolo e fasyéndolo saber a algunos de vuestros criados sy los avedes, o vecinos o religiosas o vasallos de qualquiera de los dichos monesterios o en otra qualquier manera que se presuma e vea venir a vuestra notiçia e dello non podades pretender nin alegar ygnorançia, fasta seys días próximos syguientes, los quales vos damos e asygnamos por tres plazos, dándovos los quatro días primeros 
por primero plazo e el otro día segundo por segundo plazo, e el otro día postrimero por postrimero plazo e término perentorio acabado, parescades ante nos por vos o por vuestro procurador sufiçiente con vuestro poder bastante, bien ynstructo e bien ynformado, en este dicho nuestro monesterio de Sant Martín desta dicha cibdad de Sanctiago, donde nos al presente resydimos e estamos entendiendo en la dicha reformaçión, a tomar treslado de la dicha querella e a responder a ella en guarda de vuestro derecho, e a oyr e ser presente a todos los auctos deste dicho pleyto, principales e accesorios, ynçidentes e dependientes, suscintamente uno en pos de otro fasta la sentençia deffinitia ynclusive, para la qual oyr e para ver jurar e tasar costas sy las oviere, egualmente para todos los otros auctos e cada uno dellos a que derecho devéys ser çitada e enplazada e espeçial citaçión se requiera, vos citamos e llamamos e enplazamos e ponemos plazo perentoriamente por esta nuestra carta con apercibimiento que vos fazemos, que sy paresciéredes como dicho es, vos ayremos e en todo vuestra justiçia guardaremos, en otra manera lo contrario faziendo, en vuestra absençia e rebeldía, non enbargante aquélla, avida por presençia, oyremos al dicho fiscal todo lo que dezyr e alegar quysiere, e libraremos e determinaremos en el dicho negoçio lo que fallaremos por justiçia, syn vos más citar ni llamar ni enplazar ni attender para ello. E so la dicha pena de excomunión mayor mandamos a qualquier escrivano público que para esto fuere llamado, que dé testimonio de lo que le fuere pedido e de cómo se vos notifica esta nuestra carta. En testimonio de lo qual mandamos dar e dymos esta nuestra carta, firmada de nuestro nonbre e sellada con nuestro sello, e firmada del notario ynfraescripto. Dada en el dicho nuestro monesterio de Sant Martín, a quatro días del mes de diziembre, año del Señor, de mill quatrocientos e noventa e ocho años.

(Firmado:) Frater R [udericus], S [ancti] B [enedicti] p [rior] et appostolicus reformator. Por mandado del dicho Rdo. Sr. prior reformador, Gonçalo de Nájera, notario.

«CUADERNOS DE ESTUDIOS GALLEGOS», Tomo XLIX, Fascículo 115, Santiago 2002. 


\section{DOCUMENTO 18}

1499, enero, 3. Santiago.

Petición del fiscal para que el reformador dé por concluso el pleito contra la abadesa de Dozón, que no había comparecido a declarar.

AHN, Clero, Leg. 7711. (Original).

Rdo. señor e devoto padre: Fernando de Estrada, promotor fiscal de la dicha horden de Sant Benito me encomiendo a vuestra merced, la qual bien sabe la querella e acusaçión que yo en el dicho nonbre di de doña Ysabel de Ulloa, abbadesa de los monesterios de Sant Pedro de Doçón e Ansemil, e por vuestra reverençia fue mandada dar sentençia de citaçión e enplazamiento en forma para la dicha abbadesa, que paresçiese por sy o por su procurador, la qual fue notificada segund por ella paresçe e a vuestra reverençia consta, e por mí le han seydo acusadas las rebeldías. Por ende, pido e suplico a vuestra reverençia mande aver e aya este pleito por concluso, pues no ha paresçido ni presentado alguno en su nonbre, para lo qual su noble ofiçio ynploro e las costas pido e protesto, e sobre todo pido serme fecho cunplimiento de justiçia.

\section{DOCUMENTO 19}

1499, junio, 11. San Pedro de Dozón.

Acta de toma de posesión y visita del monasterio de San Pedro de Dozón por parte del reformador.

AHN, Clero, Leg. 7727. (Original).

Año del nasçimiento de nuestro señor Ihesuchristo de mill e quatroçientos e noventa e nueve años, a honze días del mes de junio del dicho año, este dicho día, estando dentro en el monesterio de Sant Pedro de Doçon, de la horden de Sant Benito, syto en la diócesi de Lugo e estando presente Aldara Sánches, priora de dicho monesterio, por ante mí, el 
notario público e testigos ynfraescriptos paresçió presente el reverendo señor don fray Rodrigo de Valençia, prior del monesterio de Sant Benito de Valladolid, juez appostólico y reformador general de toda la horden de Sant Benito en los reynos de Castilla e Galizia, e dixo que por quanto el dicho monesterio de Sant Pedro de Doçón estava vacuo por fyn y muerte de doña Isabel de Ulloa, abbadessa que fue de dicho monesterio, última posseedora que dél fue, y porque a él como superior e prelado de la dicha horden e reformador della convenía proveer de la dicha abbadía e monesterio e avía ynbiado a tomar la possessión dél en nonbre de la dicha horden e observançia, que no se apartando de la dicha primera prossessión ni de otra qualquier que en nonbre de la dicha horden de dicho monesterio fuese tomada, porque a mayor abondamiento como mejor podía e de derecho devía, pedía e requería, pidió e requirió a la dicha priora de dicho monesterio le diese la possessión real, actual seu quasy dél, con todo lo a él anexo, devido e pertenesçiente, para la dicha horden e observançia, e luego la dicha priora dixo que ella estava e está (presta) de ge le dar, e de le poner e apoderar en ella. E luego, yncontinente, la dicha Aldara López (sic), priora, dio al dicho señor prior un cáliz e un libro e una vestimenta e la cuerta de una canpana con que tañese en señal de dicha possessión. $\mathrm{E}$ luego el dicho señor prior, resçebidas las dichas cosas en su mano, tañó la dicha canpana e echó fuera a los que dentro de dicha yglesia estavan e cerró las puertas e después las tornó a abrir, e dixo que non se apartando de la dicha primera possessión que antes avía tomado, segund dicho avía, que desde agora se dava e dio por puesto e apoderado en la dicha possessión, real, actual seu quasy de dicho monesterio con todo lo a él anexo, devido e pertenesçiente, en nonbre de la dicha horden e para la dicha observançia, e pidió a mí, el dicho notario, que ge lo diese asy por testimonio. Testigos que fueron presentes: Bernal Fernández, clérigo e capellán de dicho monesterio de Doçón, e Ochoa Yváñez de Estella, notario, e Diego Velón, merino de Samos, e Lope de Sant Fines, morador en Doçón, e Ruy Fernández Noguerol e otros.

E después de lo susodicho, yncontinente, el dicho señor prior dixo que mandava e mandó en virtud de santa obediençia e so pena de excomunión mayor a todos los vasallos, feligreses, foreros e renteros, desmeros de dicho monesterio, que de aquí adelante non acudiesen con los fructos e rentas e otras eclesyásticas derechuras al dicho monesterio devidas e pertenesçientes e persona alguna, salvo a él o a la persona o personas quel 
mandase o su poder oviese en nonbre de la dicha orden e observançia. Testigos, los dichos.

E luego, yncontinente, por ante mí, el dicho notario, la dicha Aldara López, priora, dio la obediencia al dicho señor prior reformador e a sus suscesores estando la dicha Aldara López fincada de rodillas e alçadas las manos e puestas entre las del dicho señor prior reformador y diziéndole el dicho señor prior: Promitis obedientiam et reverenciam michi et suscessoribus meis tres vezes, e respondiendo la dicha priora a cada vez: Promito. Y el dicho señor prior y ella lo pidieron asy por testimonio. Testigos, los dichos.

E después de lo susodicho, el dicho señor prior, continuando en el dicho nonbre la dicha posesión, yncontinente vysytó las cosas siguientes:

Primeramente, visitó el altar mayor, cuya vocaçión es Sant Pedro. Estavan en él quatro sábanas, un frontal de lienço pintado de figuras.

Visitó la plata y halló un cáliz de plata con su patena e otro de plomo e una cruz de plata pequeña metida en una caxa.

Visitó asymesmo las vestimentas e halló las siguientes: Una vestimenta de haumelote de seda listada, vieja con su apareja; un frontal de locaza negro aforrado en lienço colorado; dos vestimentas de lienço con su aparejo; otras dos dixo el dicho capellán que tenía en su casa; dos capas viejas de çernore? e una vestimenta de lienço vieja con su aparejo; seys sábanas de lienço.

Visitó dos libros misales en un sanctoral e un leçionario, que estavan en el dicho monesterio, enel qual asymesmo avía otros libros viejos.

E asymesmo, el mesmo dicho señor prior dixo, que porque el dicho monesterio no quedase desierto y syn servyr, que mandava e mandó a la dicha priora que estoviese e residiese en el dicho monesterio para le servir tanto quanto su voluntad fuese, e por él fuese proveydo otra cosa en contrario.

Otrosí, dexó por capellán del dicho monesterio para que le sirviese y administrase los sacramentos a los parrochianos y feligreses del dicho monesterio al dicho Bernal Fernández, clérigo, y le entregó e dio la dicha cruz de plata y el dicho cáliz de plata con que se sirviese el dicho monesterio e lo diese y entregase cada y quando que él mandase, a la persona que él nonbrase o su poder oviese e non a otra persona alguna, e el dicho capellán lo resçibió e juró en forma devida de derecho de lo tener e guardar e acudir con ello al dicho señor prior e a quien mandase e su poder oviese, 
y para ello obligó a sy e a sus bienes spirituales y tenporales, etc., y otorgó obligaçión forte e firme, con renunçiaçión de leys, y poder a las justiçias, e carta que paresciee signada de mi sygno. Lo qual todo lo que dicho es fue e pasó ansy en el dicho monesterio, día, mes e año sobredicho e testigos los dichos.

\section{DOCUMENTO 20}

1499, junio, 13. San Pedro de Ansemil.

\section{Acta de toma de posesión y visita del monasterio de San Pedro de Ansemil por parte del reformador.}

AHN, Clero, Leg. 7727. (Original).

Año del nasçimiento de nuestro señor Ihesuchristo de mill e quatroçientos e noventa e nueve años, a treze días del mes de junio del dicho año, este dicho día, estando dentro en el monesterio de San Pedro de Ansemil, syto en la diócesi de Lugo, de la horden de Sant Benito, por ante mí, el dicho notario público e testigos de ynfraescriptos, paresçió presente el reverendo señor don fray Rodrigo de Valençia, prior del monesterio de Sant Benito de Valladolid, juez appostólico y reformador general de toda la horden de Sant Benito en los reynos de Castilla e Galizia, e dixo que por quanto el dicho monesterio de Sant Pedro de Ansemil estava vacuo por fyn y muerte de doña Isabel de Ulloa, abbadessa que fue de dicho monesterio, última poseedora que dél fue, y él avía ynbiado a tomar la posesyón de dicho monesterio en nonbre de la dicha horden, que él no se apartando de la dicha possessyón ni de otra qualquier que en nonbre de la dicha horden del dicho monesterio fuese tomada, e agora como mejor podía e de derecho devía asy como superior y prelado de la dicha horden de Sant Benito y como reformador della a quien pertenesçía resçebir, aprehendía e tomava, aprehendió, resçibió e tomó la posesyón real, actual, seu quasy del dicho monesterio con todo lo a él anexo, devido e pertenesçiente en qualquier manera en nonbre de la dicha horden e para la dicha observançia, e que para en señal de la dicha posesyón tomava e tomó una vestimenta e un cáliz e un libro e hizo tañer la canpana de dicho

«CUADERNOS DE ESTUDIOS GALLEGOS», Tomo XLIX, Fascículo 115, Santiago 2002. 
monesterio, e hizo cerrar las puertas dél e echar fuera a todos los que dentro estavan e después las abrió y dixo que él se dava e dio por puesto e apoderado en la dicha posesyón real, actual, seu quasy del dicho monesterio, con todo lo a él anexo, devido e pertenesçiente en nonbre de la dicha horden e para la dicha observançia. E pidió a mí, el dicho notario, lo diese por testimonio, segund que mejor e más cunplidamente lo podiese dar e hordenar a consejo de letrado, e a los presentes rogó que fuesen dello testigos. Testigos que fueron presentes: Ruy Gómez de Sevil, merino de tierra de Deça, e Martino Alvares, su hijo, e Lope Conde, vesyno de Mellide, e Diego Velón, vesyno e merino de Samos, e Fernando de Estrada, Pedro de Villarroel, escuderos, e fray Pedro de Maçuelo e fray Pedro de Çamora, prior del monesterio de Sant Benito de Çamora, e fray Rodrigo de Peñafiel, monjes profesos de la dicha horden de Sant Benito e otros.

E después de los susodicho, luego yncontinente, el dicho señor prior dixo que mandava e mandó en virtud de santa obediençia, so pena de excomunión mayor, a todos los vasallos e feligreses, foreros e renteros que fuesen del dicho monesterio, que non acudiesen con los fructos y rentas y eclesyásticas derechuras al dicho monesterio devidos e pertenesçientes, salvo a él o a la persona o personas que por su mandado en el dicho monesterio estoviesen o su poder toviesen en nonbre de la dicha horden de Sant Benito, y que asymesmo mandava e mandó a todos e qualesquier personas, asy eclesyásticas como seglares de qualquier estado o condiçión que fuesen deste dicho reyno, so la dicha pena de excomunión mayor e de perdimiento de sus bienes, por virtud de las provisyones que de sus altezas tenía, que non fuesen osados de se entrometer a parturbar ni molestar la dicha posesyón quel asy avía tomado y aprehendido en nonbre de la dicha horden e para la observançia, e pidiólo por testimonio. Testigos, los sobredichos.

E después de lo susodicho, en el dicho monesterio de Sant Pedro de Ansemil en el dicho día, mes y año sobredichos, por ante mí el dicho notario e testigos sobredichos, el dicho señor prior dixo que por quanto después de aver asy tomado la dicha posesyón del dicho monesterio el licençiado Alonso de Pomareda, corregidor de la villa de Sarria e logarteniente para las cosas de la dicha reformaçión por el señor licençiado Alonso Maldonado, del Consejo del rey y reyna, nuestros señores e su alcalde mayor deste dicho reyno de Galizia, ponía en el dicho monesterio en nonbre de sus altezas, lo toviere de secresto e de manifiesto al dicho 
Martino Alvarez, no lo podiendo ni deviendo fazer asy por él aver ya tomado la dicha posesyón como dicho es, como por quel dicho corregidor non tenía poder para ello syno para desencastellar y hazer llanos todos los monesterios e casas de la dicha horden que estoviesen encastelladas para que libremente los podiese visytar e reformar al thenor de sus poderes que presentava y presentó, que todo lo quel dicho corregidor fasya o fesyese contra la dicha su possessión y el secresto que posiese fuese en sy ninguno e de ningund valor e effecto, e que non parase prejuisyo a la dicha su posesyón, quel en nonbre de la dichahorden de Sant Benito avía tomado. E asymesmo protestava e protestó que cayese e yncurriese en las censuras y penas que arriba tenía puestas por yr contra la dicha su posesyón e contra los dichos sus mandamientos y poderes, e demás de aver e de cobrar dél e de sus bienes todos los gastos, dapnos y menoscabos que el dicho monesterio de Sant Pedro de Ansemil e a sus fructos y rentas y a la dicha horden de Sant Benito en su nonbre viniesen e se les recresçiesen. Y pidiólo por testimonio. E el dicho corregidor dixo que él daría su respuesta. Testigos, los dichos.

E después de los susodicho, en el dicho monesterio de Sant Pedro de Ansemil, en el dicho día, mes e año sobredichos, por ante mí, el dicho notario y testigos de yusoescriptos el dicho señor prior dixo al dicho señor licençiado Alonso Maldonado, que estava presente, que por quanto él viniendo personalmente a visytar e reformar el dicho monesterio, segund e por el nuestro muy sancto padre e por sus altezas le hera cometido e mandado e él lo avía hallado encastillado con gente armada y le avía seydo resistida la entrada en él, y que después el dicho corregidor lo avía desencastillado, y asy desencastillado oy dicho día él avía tomado la posesyón del dicho monesterio arriba contenida y segund y por ante mí el dicho notario avía pasado. Y que después de asy tomada la dicha possesyón, el dicho corregidor, que asymesmo estava presente, lo avía puesto de secresto e de manifiesto en manos e poder de Martino Álvarez, que también estava presente, lo qual avía fecho ynjusta e non devidamente non teniendo poder nin facultad para ello, espeçialmente seyendo como era y es el dicho monesterio de la dicha horden de Sant Benito, y que para ello le presentava y le presentó luego çierta ynformaçión y pesquisa de cómo el dicho monesterio de Ansemil era e es de la dicha horden de San Benito, que pedía e requería, pidió e requirió al dicho señor licençiado Maldonado e por virtud de los dichos poderes appostólicos e reales, le mandava e

«CUADERNOS DE ESTUDIOS GALLEGOS», Tomo XLIX, Fascículo 115, Santiago 2002. 
mandó que le amparase e defensiese, e mandase amparar y defender en la dicha su posesyón que en el dicho nonbre avía tomado, e alçase luego el dicho secresto que el dicho corregidor avía puesto, e lo diese todo por ninguno, e mandase a todas las justiçias e a otras personas qualesquier destse reyno que no le perturbasen ni molestasen en la dicha su posesyón, mas antes mandase que le amparasen e defendiesen en ella e le mandase acudir con los frustos e rentas y otras eclesyásticas derechuras al dicho monesterio e a él en su nonbre devidas e pertenesçientes, e pidiólo por testimonio.

E luego el dicho señor licençiado Maldonado dixo que él avia venido de la cibdad de Sanctiago por ynvocaçión e auxilio del braço real, que por parte del dicho señor prior le fue notificado e pedido, e porque asymesmo avía sido requerido por su parte con çiertas provisyiones de sus altezas para que viniese a desencastillar e fazer llano el dicho monesterio, para que lo podiese visytar e reformar al thenor de sus poderes, por quanto le avian dicho que estava encastillado e le constava por testimonio sygnado de escribano público. Y que pues éllo avía hallado desencastillado y el dicho señor prior avía tomado la dicha posesyón del dicho monesterio, el qual por la dicha ynformaçión e pesquisa le constava e constó ser de la dicha horden de Sant Benito, que él como mejor podía e devía de parte de sus altezas amparava e defendía, amparó e defendió al dicho señor prior en nonbre de la dicha horden de Sant Benito o a quien su poder toviese en la dicha posesyón del dicho monesterio con todo lo a él anexo e pertenesçiente, e que alçava e alçó el secresto por el dicho corregidor puesto en el dicho monesterio en los fructos e rentas dél, e que lo dava e dio por ninguno e de ningund valor e effecto, e que asymesmo alçava e alçó qualquier pleyto, omenaje e juramento que el dicho Martino Albares sobrello oviese fecho, para quel dicho señor prior libremente podiese continuar la dicha su posesyón y visita, y reformar el dicho monesterio, e fazer dél e en él todo lo que por el nuestro muy sancto padre e por sus altezas le hera cometido e mandado, bien e asy e tan cumplidamente y como mejor lo podía fazer, seyendo viva la dicha abbadesa como después de fallesçida e tomada la dicha posesyón. E que mandava e mandó a todos los feligreses e perrochianos, diezmeros e renteros e redituarios del dicho monesterio que acudiesen con todos los fructos e rentas e otras eclesyásticas derechuras al dicho señor prior o a quien su poder toviese, bien e tan cumplidamente como lo pagavan e acudían a la dicha abbadesa e eran obligados, so pena de diez mill maravedís para la cámara e fisco de 
sus altezas. E que asymesmo mandava e mandó a todas e qualesquier personas, asy ecclesyásticas como seglares de qualquier estado o condiçión que fuesen, que non perturbasen ni molestasen ni ynquietasen al dicho señor prior o a quien su poder toviese en la dicha posesyón, so pena a las personas legas de perdimiento de todos sus bienes, e a las eclesiásticas so pena de perder qualesquier tenporalidades que toviesen en estos reynos, $\mathrm{e}$ de ser avido por agenos e estraños dellos, e de proçeder contra ellos a las penas en que tanbién yncurren aquellos que por su propia aubtoridad se entrometen a perturbar lo susodicho. E que asymesmo mandava e mandó a todas las justiçias deste dicho reyno que anparasen e defendiesen al dicho señor prior e a la dicha horden de Sant Benito o a quien su poder toviese en la dicha posesyón, e non consyntiesen ni diesen logar que por alguna ni algunas personas della fuese amovido e quitado, perturbado ni molestado fasta tanto que sobrello fuese oydo e vençido por fuero e por derecho ante quién e cómo deviese. E por quanto desya que los freyles de la horden de Sant Bernardo tenían algún derecho al dicho monesterio, que él les reservava e reservó su derecho a salvo para que lo pudiesen pedir e demandar ante quién e cómo con derecho deviesen. E luego el dicho Martino Alvares dixo que obedesçía e obedesçió lo que por el dicho señor licençiado Maldonado mandado, e que entregava e entregó al dicho señor prior el dicho monesterio e le dio luego un cáliçe de plata que tenía, e dixo que estava presto de dar e entregar todo lo que avía resçebido de mano del dicho señor corregidor, el qual asymesmo luego alçó el juramento e pleito, omenaje al dicho Martino Álvarez, que le tenía fecho e tomado e el dicho señor prior lo tomó por testimonio. Testigos que estavan presentes: Pedro de Gayoso, vecino de la cibdad de Lugo, e Lope de Meyro e Luys Bermúdez, escuderos, e Fernando de Estrada e Diego Velón, merino de Samos,e Ochoa Yváñez Destella, notario, e Vasco López de Reçelle, vecino de Reçelle, e Gonzalo de Bandes e Juan de Canta, vecinos del coto del dicho monesterio de Ansemil, e Pero Sánchez, procurador que se dixo de la orden de Sant Bernardo e otros muchos.

E después de lo susodicho, yncontinente, el dicho señor prior continuando la dicha posesyón del dicho monesterio de Ansemil, visytó las cosas siguientes:

Primeramente visytó el altar mayor, cuya vocaçión es San Pedro Apóstol. Estavan en él dos sávanas de lienço, e la una labrada de hilo de colores, e una ara con sus corporales, e dos cruces de metal.

«CUADERNOS DE ESTUDIOS GALLEGOS», Tomo XLIX, Fascículo 115, Santiago 2002. 
Visytó un altar de la capilla a la mano derecha, que se llama Santa Anna. Estavan en él dos sávanas e un frontal negro de hilo e una ara.

Visytó asymesmo las vestimentas y halló las syguientes: Tres vestimentas de lienço, con sus cruces, petos y sus aparejos. Una casulla de zarzahán de seda con sus leones blancos, vieja, con su aparejo. Tres alvas viejas e una sávana pequeña e outra casulla de lienço e otra de zarzahán de hilo.

Visytó los libros e halló los siguientes: Un misal de pergamino nuevo, bueno; un evangelistero e un ofiçiero (sic); un epistolero; un responsorio dominical, todos de pergamino, con otros librillos viejos.

Otrosy, visytó otros dos altares, uno vocaçión de Sant Benito, e el otro de Santa María Magdalena.

Yten, falló un caliñe de plata con su patena, dorado el bevedero con la copa dél.

A lo qual fueron presentes por testigos, los devotos padres fray Pedro de Maçuelo e fray Pedro de Çamora e fray Rodrigo de Peñafiel, monjes profesos de la dicha horden, e el dicho licençiado Alonso de Pomareda, e el dicho Martino Alvares, e Gonzalo de Vandes e Juan de Canba e Juan de Castro, vasallos de dicho monesterio e otros.

(Firmado:) Gonçalo de Nájera, notario. 